\title{
DEVELOPMENT OF A RECIPE FOR A MULTICOMPONENT MIXTURE «SOLODOK +» TO IMPROVE THE CONSUMER PROPERTIES OF BAKERY PRODUCTS
}

\author{
Olena Bilyk', Yulia Bondarenko ${ }^{2}$, Oksana Kochubei-Lytvynenko ${ }^{3}$, Liudmyla Burchenko $^{4}$ \\ ${ }^{1}$ Department of Technology of Bakery and Confectionery Products, National University of Food Technologies, Kyiv, Ukraine \\ ORCID: https://orcid.org/0000-0003-3606-1254 \\ ${ }^{2}$ Department of Technology of Bakery and Confectionery Products, National University of Food Technologies, Kyiv, Ukraine \\ ORCID: https://orcid.org/0000-0002-3781-5604 \\ ${ }^{3}$ Department of Milk and Dairy Technology, National University of Food Technologies, Kyiv, Ukraine \\ ORCID: https://orcid.org/0000-0003-0712-448X \\ ${ }^{4}$ Department of Technology of Bakery and Confectionery Products, National University of Food Technologies, Kyiv, Ukraine \\ ORCID: https://orcid.org/0000-0002-5413-961X \\ ${ }^{\otimes}$ Corresponding author: Olena Bilyk, e-mail: bilyklena@gmail.com
}

\begin{tabular}{l} 
A R T ICLE INF O \\
\hline Article history: \\
Received date 09.11 .2021 \\
Accepted date 14.12 .2021 \\
Published date 30.06 .2021 \\
Section: \\
Food production \\
D O I
\end{tabular}

$10.21303 / 2313-8416.2021 .002235$

KEYWORDS

mixture of germinated grains multicomponent mixture

bakery products

consumer properties

\section{ABSTRACT}

The object of research is the technology of bakery products enriched with a mixture of germinated grains of wheat, corn, barley and oats.

Investigated problem: The problem of using a mixture of germinated grains is the formation of a closure sticky crumb in baked goods with a mixture. The reason for this is the high activity in the mixture of amylolytic and proteolytic enzymes.

The solution to the problem consists in the developed multicomponent mixture (MM) to improve the consumer properties of bakery products, the formulation of which includes $15 \%$ of the flour mass of the germinated grain mixture.

Main scientific results: On the basis of experimental studies, the formulation of the "Solodok+" multicomponent mixture has been developed. The mixture contains: chicory inulin, dry milk whey enriched with $\mathrm{Mg}$ and $\mathrm{Mn}$, apple pectin, phosphatide concentrate, enzyme preparation Deltamalt FN-A 50 and ascorbic acid. The optimal dose of the "Solodok+" MM for bakery products is $2.5 \%$ by weight of flour.

The area of practical use of the research results: "Solodok+" MM is recommended to be used in the production of bakery products enriched with sprouted grains at enterprises of the bakery industry of various capacities.

An innovative technological product: "Solodok+" MM helps not only to reduce the stickiness of the crumb, improve its porosity, increase the volume of products, but also lengthen the freshness of unpackaged products.

Scope of application of the innovative technological product: Bakery products with a mixture of sprouted grains and "Solodok+" MM have increased nutritional value, high consumer properties and are intended for a wide range of consumers.

(c) The Author(s) 2021. This is an open access article under the Creative Commons CC BY license

\section{Introduction}

Bakery products containing up to $14 \%$ of the flour mass, sugar and fat, have high consumer properties. Such as the volume of products, dimensional stability, developed porosity, soft crumb, pleasant taste and aroma [1]. To improve the biological value of bakery products, a variety of non-traditional raw materials are introduced into the recipe [2, 3]. Scientists have established the feasibility of using a mixture of germinated grains (MGG) of wheat, corn, barley and oats for enriching bakery products with dietary fiber, nonessential and irreplaceable amino acids, microelements and macroelements and vitamins [4].

In the process of germination of cereal crops, the enzymatic complex of grains is activated, and therefore the MGG has a high autolytic activity [4]. Therefore, when using flour of sprouted grains in the technology of bakery products, on the one hand, it intensifies the process of fermentation and accumulation of dextrins, and on the other hand, worsens the crumb structure, namely, stickiness appears [5].

To improve the consumer properties of bakery products, manufacturers in most cases use complex bakery improvers, multicomponent mixtures. The purpose of their use is to adjust the baking properties of flour, intensify the process of maturation of the dough, improve organoleptic 
and physicochemical quality indicators and prolong the duration of freshness $[6,7]$. Therefore, it is relevant to develop a recipe for a multicomponent mixture (MCM) to improve the quality of bakery products in the recipe of which $15 \%$ is included in the flour mass of the mixture of germinated grains of wheat, corn, barley and oats.

In the process of developing the MCM formulation, much attention is paid to the direction of action of this mixture for the selection of the necessary ingredients and food additives. Therefore, it is proposed to use apple pectin, chicory inulin, dry milk whey enriched with $\mathrm{Mg}$ and $\mathrm{Mn}$ as water-retaining additives [8-10].

Apple pectin is a safe food additive designed to improve the consumer properties of baked goods due to its high water-holding capacity and the ability to form complexes with gluten and prolong the freshness of baked goods [11].

Inulin is a natural polysaccharide consisting of $\beta$-2-1-bonds of $D$-fructafuranose residues and ending with $\alpha$-D-glucopyranose residue, which is a safe ingredient for bakery products. The addition of inulin to the composition of bakery products has a beneficial effect on the dough preparation process, increases the stability and elasticity of the dough and regulates the absorption of water. Therefore, it is advisable to include it in the MCM formulation to increase the durability and elasticity of the dough, the formulation of which includes MGG [9].

The National University of Food Technologies (Ukraine) has developed a technology for enrichment of dry milk whey with $\mathrm{Mg}$ and $\mathrm{Mn}$ [10]. It was found that whey powder enriched with $\mathrm{Mg}$ and $\mathrm{Mn}$ is a good functional basis in the production of complex bakery improvers [12]. Powdered milk whey enriched with $\mathrm{Mg}$ and Mn was selected for the MCM formulation to reduce the activity of enzymes in germinated grains.

The use of phosphatide concentrates can be considered one of the most effective methods that slow down the process of starch retrogradation and the release of water by proteins during storage [13]. The authors of [14] recommend the use of defatted hydrolyzed phosphatide concentrates in the technology of bakery products. Soy defatted dry phosphatide concentrate was selected for inclusion in the MCM formulation for bakery products.

To level the activity of enzymes in the case of using flour from sprouted grains in the technology of bakery products, the German company "Muhlenchemie" has developed an enzyme preparation Deltamalt FN-F50, which reduces atolytic activity in the dough, improves the quality of finished products, increases the specific volume, as well as crust crunch [15].

It is recommended to use ascorbic acid as a safe food additive with oxidative action in the technology of bakery products. Ascorbic acid helps to bleach the crumb, increase the shape stability of the dough piece during standing and baking, and improve the structural and mechanical properties of the dough [16].

The object of research in the work were dough and finished products from flour of the highest grade flour, dough and finished products with $15 \%$ by weight of flour MGG and dough and finished products with $15 \%$ by weight of flour MGG and MCM.

The aim of research is to establish a rational dosage of prescription ingredients of the MCM and to investigate the influence of the developed MCM on the consumer properties of bakery products.

\section{Materials and Methods}

When developing the MCM formulation, the following raw materials were used: MGG, Polish-made apple pectin, Ukrainian-made inulin, ascorbic acid produced in China, powdered milk whey enriched with $\mathrm{Mg}$ and $\mathrm{Mn}$, and the German-made Deltamalt FN-F50 enzyme preparation. To assess the quality of baked goods with the MGG addition, apple pectin, inulin, ascorbic acid, dry milk whey enriched with $\mathrm{Mg}$ and $\mathrm{Mn}$, the enzyme preparation Deltamalt FN-F50, a laboratory baking test was carried out according to the recipes given in Table $\mathbf{1}$.

The dough preparation was carried out in an Esher kneading machine (Italy) at the first speed for 6 minutes and at the second speed for 6 minutes. The dough was processed manually, the dough pieces were allowed to stand in a cabinet at a temperature of $38 \pm 2^{\circ}$ and a relative humidity of $78 \pm 2 \%$ until cooked. The products were baked in a Sveba-Dahlen cabinet oven at a temperature of $200 \ldots 220^{\circ} \mathrm{C}$ with humidification of the baking chamber for $25 \ldots 30$ minutes. 
Table 1

Formulations of the studied samples

\begin{tabular}{ccc}
\hline Ingredients & & Content, kg \\
\cline { 2 - 3 } & Control (no additives) & Bakery product with MGG \\
\hline Wheat flour of the highest grade & 100 & \\
Pressed bakery yeast & 3.0 & \\
Table salt & 1.5 & \\
White sugar & 2.0 & 15.0 \\
Sunflower oil & 2.0 & 15
\end{tabular}

Consumer properties of finished products were assessed by physicochemical (specific volume, acidity) and organoleptic indicators (appearance, condition of the crust surface, structure of porosity, taste, odor) [8]. The complex quality indicator was assessed by the point assessment of the quality of bakery products [17]. The comprehensive quality indicator took into account the quality indicators of bread, namely:

- specific volume;

- correctness of the form;

- crust color;

- staleness after 72 hours;

- condition of the crust surface;

- crumb color;

- porosity structure;

- form stability of hearth bread;

- rheological properties of the crumb;

- bread aroma;

- bread taste;

- crumb chewiness.

Each indicator is assessed on a five-point scale. Each point characterizes a certain level of quality: "5" - excellent; "4" - good; "3" - satisfactory; "2" - not satisfactory enough; "1" - unsatisfactory. To assess the quality of bakery products, determined by objective methods, they are calculated with an accuracy of 0.2 points, and the indicators of organoleptic assessment (the arithmetic average of 3-5 tasters) are expressed with an accuracy of 0.1 points.

The quality of bakery products is assessed as the sum of points:

$$
K_{\hat{\imath}}=\sum_{i=1}^{i=n} m_{i} x_{i},
$$

where $K_{o}$ - comprehensive assessment of the bread quality, points; $m_{i}$ - the coefficient of the weight of each indicator; $x_{i}$-assessment of each indicator on a five-point scale; $i$ - bread quality indicator; $n$ - the number of characteristics.

This formula takes place if $x \geq 2$, in the case of $x<2$, bread is recognized as unsatisfactory in quality, regardless of the amount of points. The quality of bakery products by the totality of all characteristics, taking into account the weight coefficients, is determined with an accuracy of 0.1 points. The highest possible quality score is 100 points.

The gas-holding capacity of the dough was determined by the change in the specific volume of $100 \mathrm{~g}$ of dough in the cylinder during the monitoring of the dough and the standing of the dough pieces [17]. The results of experimental studies were subjected to statistical processing using standard Microsoft Office software packages.

\section{Results}

To develop a recipe for the "Solodok+" MCM to improve consumer properties and lengthen the freshness of bakery products, the recipe of which includes $15 \%$ of the mass of MGG flour, laboratory baked goods were carried out. The purpose of these studies is to determine the optimal dosage of each ingredient in the bakery dough. The optimal dosage of each ingredient and food ad- 
ditive was determined by the scoring of finished products, improved for bakery products with long shelf life, and a comprehensive quality indicator was determined. The dosage of each ingredient and food additive was carried out according to the manufacturer's recommendations for each product separately. Food additives are included in the recipes of the "Solodok+" MCM, which neutralize the negative effect of the high autolytic activity of the mixture of germinated grains and having the GRAS status, i.e. safe [18]. The ingredients are chicory inulin, dry milk whey enriched with $\mathrm{Mg} \mathrm{Mn}$; as food additives: apple pectin, phosphatide concentrate, enzyme preparation Deltamalt, ascorbic acid. The results of laboratory baking are shown in Table 2.

\section{Table 2}

Determination of the optimal dosage of prescription components of a multicomponent mixture according to a complex quality indicator, $n=3, p \geq 0.95, \delta 3 \ldots 5 \%$

\begin{tabular}{|c|c|c|c|c|c|c|c|}
\hline Indicator & Control (no additives) & From $15 \%$ to the mass of MGG flour & \multicolumn{5}{|c|}{ Dosage (\%) by weight of flour } \\
\hline complex & \multirow{3}{*}{85.6} & \multirow{3}{*}{76.6} & \multicolumn{5}{|c|}{ Chicory inulin } \\
\hline \multirow{2}{*}{$\begin{array}{l}\text { quality } \\
\text { indicator }\end{array}$} & & & 0.5 & 1.0 & 1.5 & 2.0 & 2.5 \\
\hline & & & 79.6 & 80.1 & 81.2 & 82.6 & 82.6 \\
\hline complex & \multirow{3}{*}{85.6} & \multirow{3}{*}{76.6} & \multicolumn{5}{|c|}{ Whey powder enriched with Mg and Mn } \\
\hline \multirow{2}{*}{$\begin{array}{l}\text { quality } \\
\text { indicator }\end{array}$} & & & 0.25 & 0.50 & 0.75 & 1.0 & 1.25 \\
\hline & & & 80.6 & 82.4 & 84.2 & 87.1 & 87.3 \\
\hline complex & \multirow{3}{*}{85.6} & \multirow{3}{*}{76.6} & \multicolumn{5}{|c|}{ Apple pectin } \\
\hline \multirow{2}{*}{$\begin{array}{l}\text { quality } \\
\text { indicator }\end{array}$} & & & 0.3 & 0.6 & 0.9 & 1.2 & 1.5 \\
\hline & & & 79.5 & 80.1 & 81.0 & 82.4 & 82.3 \\
\hline complex & \multirow{3}{*}{85.6} & \multirow{3}{*}{76.6} & \multicolumn{5}{|c|}{ Phosphatide concentrate } \\
\hline \multirow{2}{*}{$\begin{array}{l}\text { quality } \\
\text { indicator }\end{array}$} & & & 0.1 & 0.2 & 0.4 & 0.6 & 0.8 \\
\hline & & & 77.5 & 79.1 & 81.4 & 83.6 & 83.6 \\
\hline complex & \multirow{3}{*}{85.6} & \multirow{3}{*}{76.6} & \multicolumn{5}{|c|}{ Enzyme preparation Deltamalt } \\
\hline \multirow{2}{*}{$\begin{array}{l}\text { quality } \\
\text { indicator }\end{array}$} & & & 0.001 & 0.002 & 0.004 & 0.006 & 0.008 \\
\hline & & & 77.2 & 82.6 & 85.8 & 85.9 & 85.9 \\
\hline complex & \multirow{3}{*}{85.6} & & \multicolumn{5}{|c|}{ Ascorbic acid } \\
\hline quality & & 76.6 & 0.01 & 0.05 & 0.1 & 0.15 & 0.20 \\
\hline indicator & & & 78.2 & 81.6 & 81.6 & 81.5 & 81.4 \\
\hline
\end{tabular}

Based on the results of test baking of a bakery product made with different recipe components of the MCM, complex quality indicators were calculated (Table 1). It has been established that, according to the complex quality indicator, the rational dosages of the constituents in $\%$ to the flour mass in the recipe for bakery products made from MGG are: chicory inulin - 2.0; dry milk whey enriched with $\mathrm{Mn}$ and $\mathrm{Mg}-1.0$; apple pectin - 1.2; enzyme preparation Deltamalt A 50 0.004; phosphatide concentrate -0.6 ; ascorbic acid -0.1 .

When formulating the MCM, it is recommended by scientists and manufacturers that a rational dosage of food additives and food ingredients for the quality of finished products be halved to form the MCM formulation due to a synergistic effect, subject to joint application [19].

As a result of the research carried out, the formulation of the "Solodok+" milticomponent mixture ("Solodok+" MCM) was developed, which is designed to intensify the technological process, improve consumer properties and lengthen the freshness of bakery products, the formulation of which includes $15 \%$ of the MGG flour mass. The recipe for ("Solodok+"MCM) is given in Table 3.

For further studies of the influence of the developed "Solodok+" MCM on the consumer properties of finished products, in the case of the production of bakery products, the recipe of which contains $15 \%$ by weight of MGG flour, a dosage of $2.5 \%$ by weight of flour was chosen.

Subsequent studies were devoted to the influence of the developed "Solodok+" MCM on the technological process of making bakery products. When baking, they used flour of the highest grade, medium and strong in strength. The data obtained were compared with the obtained control data (without additives) and with the products of the germinated grain mixture. The results of laboratory baking and research on the influence of "Solodok+" MCM are shown in Table 4 and Fig. 1. 
Table 3

The recipe for the "Solodok+" MCM

\begin{tabular}{ccc}
\hline Raw materials & $\begin{array}{c}\text { Optimal dosage (\%) to the flour mass } \\
\text { in the «Niva» loaf recipe made from } \\
\text { premium flour }\end{array}$ & $\begin{array}{c}\text { Consumption of raw materials, kg } \\
\text { per 100 kg } \\
\text { of PCS } \text { Solodok+ MCM» }\end{array}$ \\
\hline Chicory inulin & 1.0 & 40.8 \\
Powdered milk whey enriched with Mn and Mg & 0.5 & 20.4 \\
Apple pectin & 0.6 & 24.5 \\
Phosphatide concentrate & 0.3 & 12.2 \\
Enzyme preparation Deltamalt FN-A 50 & 0.002 & 0.1 \\
Vitamin C & 0.05 & 2.0 \\
Total & 2.452 & 100.0
\end{tabular}

Table 4

The impact of "Solodok+" MM on the technological process and quality of bakery products, $n=3, p \geq 0.95$, $\delta 3 \ldots 5 \%$

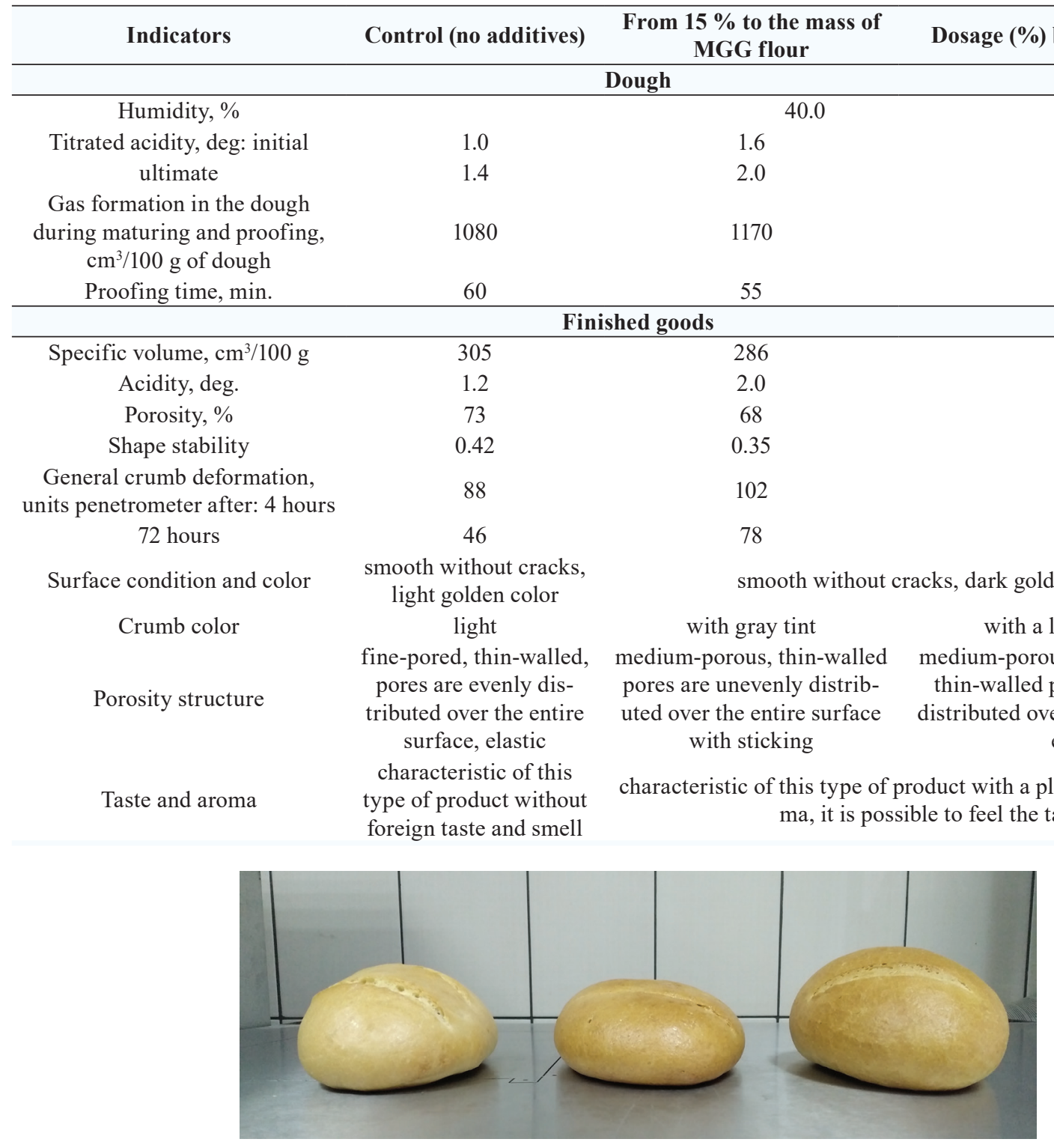

Fig. 1. Photos of finished products: 1 - control of the bakery product; 2 - a bakery product with $15 \%$ of the mass of MGG flour; 3 - bakery product with $15 \%$ by weight of flour MGG and "Solodok+" MCM 


\section{Discussion}

As a result of the studies (Table 2), in terms of quality, it was found that with a MGG dosage in an amount of $15 \%$ to the mass of flour of a bakery product, there is a deterioration in the organoleptic indicators of the quality of finished products and structural and mechanical properties, which is explained by the excessive activity of amylases. A recipe for "Solodok+" MCM has been developed (Table 3), which has a positive effect on the quality of a bakery product enriched with MGG.

"Solodok+" MCM has a positive effect on the rheological properties of the dough. The standing time of the bakery product from $15 \%$ to the mass of flour MGG and a bakery product from MGG from "Solodok+" MCM is 55 minutes, which is 5 minutes less than the control sample (Table 4). The titrated acidity of the test increases compared to the control sample. Gas formation in the dough made from "Solodok+" MCM increases in comparison with the control sample by $16.9 \%$, which is a prerequisite for an increase in the specific volume in finished products.

Due to the use of the developed "Solodok+" MCM (Table 4), the specific volume of bakery products increases by $10.6 \%$ in the product with the addition of $15 \%$ to the mass of MGG flour to the mass of flour and by $4.7 \%$ in comparison with the control sample. The shape stability of the products is improved. With the addition of "Solodok+" MCM, the porosity parameters of the products are improved. Thus, a prototype made of "Solodok+" MCM has a porosity of $77 \%$, which is $11.7 \%$ more than a product made of $15 \%$ MGG to flour weight and $5.2 \%$ more than the control sample.

Comparative analysis of the degree of preservation of the studied samples of freshness (Table 4) showed a positive effect of the "Solodok+" MCM on the process of preserving freshness. When adding $15 \%$ to the flour mass and "Solodok+" MCM to the MGG dough, the general, plastic and elastic deformation of the crumb improves. The developed multicomponent mixture improves the preservation of freshness products. Thus, the loss of freshness of a bakery product enriched with MGG after 72 hours decreases by $5.7 \%$, which is $44.3 \%$ less than in the control sample.

The addition of "Solodok+" MCM and MCM has a positive effect on organoleptic indicators (Table 4, Fig. 1). The color of the crumb of the products lightens. The porosity structure becomes uniform, the pores are thin-walled and medium in size. The pulp becomes elastic, wrinkling and stickiness disappear. Products have a pleasant taste and aroma, it is possible to feel the taste of sprouted cereals.

Consequently, the use of the developed "Solodok+" MCM leads to an improvement in the consumer characteristics of baked goods in the receptor of which $15 \%$ of the flour mass of the mixture of germinated grains of wheat, barley, oats, and corn is included.

By limiting the use of the "Solodok+" MCM multicomponent mixture in products with a mixture of germinated grains, their influence on the formation of the structural and mechanical properties of the dough, in particular the appearance of adhesion, can be. Subsequent research will be aimed at studying the structural and mechanical properties of the dough, which includes a mixture of germinated grains and a "Solodok+" MCM and dough mixing mod.

\section{Conclusions}

Using the method of scoring and a complex quality indicator, formulations of the "Solodok+" MCM have been developed for use in the technology of bakery products, in the formulation of which $15 \%$ by weight of flour is used, which includes: chicory inulin, dry milk whey enriched with $\mathrm{Mg}$ and Mn, apple, phosphatide concentrate, enzyme preparation Deltamalt FN-A 50 and ascorbic acid Optimal dosage of the "Solodok+" MCM for bakery products $-2.5 \%$ by weight of flour.

It was found that the use of the developed "Solodok+" MCM improves the quality of baked goods, namely, the specific volume of baked goods increases by $10.6 \%$ in the product with the addition of $15 \%$ to the mass of MGG flour to the mass of flour and by $4.7 \%$ in comparison with control sample. The shape stability of the products is improved, their freshness is lengthened in the case of their manufacture using accelerated technology, namely, using the safety-free method, where the fermentation process is replaced by 20 -minute maturation.

\section{References}

[1] Kuzo, N. Ye., Kosar, N. S. (2017). The study of bread and baked goods market of Ukraine and justification of product innovations conducted by manufacturers on that market. Kharchova nauka i tekhnolohiia, 4, 12-17. 
[2] Koriachkina, S. Ia., Matveeva, T. V. (2013). Funktsionalnye pischevye ingredienty i dobavki dlia khlebobulochnykh i konditerskikh izdelii. Saint Petersburg: GIORD, 628.

[3] Iorhachova, K. H., Lebedenko, T. Ye. (2015). Khlibobulochni vyroby ozdorovchoho pryznachennia z vykorystanniam fitodobavok. Kyiv: K-Pres, 464.

[4] Nartsiss, L. (2007). Tekhnologiia solodorascheniia. Saint Petersburg: Professiia, 180.

[5] Burchenko, L. M., Bilyk, O. A., Bondar, V. I. (2019). Proroshchene zerno -neotsinennyi skarb. Innovatsiini tekhnolohii u khlibopekarskomu vyrobnytstvi. Kyiv: NUKhT, 53-56.

[6] Korshenko, L. (2014). Stabilization of wheat bread's quality with low baking properties. Naukovedenie, 6 (6). doi: http://doi.org/ 10.15862/115tvn614

[7] Shevre, S. (2008). Kak sdelat produktsiiu luchshe. Khlebopekarskoe i konditerskoe delo, 2, 40-42.

[8] Aimeson, A. (2012). Pischevye zagustiteli, stabilizatory, geleobrazovateli. Saint Petersburg: Professiia, 408.

[9] Shchelakova, R., Evdokymova, H., Dmytryeva, T. (2006). Yspolzovanye ynulyna pry proyzvodstve bulochky «Stolychnoi». Naukovi pratsi Odeska natsionalna akademiia kharchovykh tekhnolohii, 2 (29), 151-155.

[10] Ukrainets, A., Kochubei-Lytvynenko, O., Bilyk, O., Zakharevych, V., Vasylchenko, T. (2016). A study of the effect of enriched whey powder on the quality of a special-purpose bread. Eastern-European Journal of Enterprise Technologies, 2 (11 (80)), 32-41. doi: http://doi.org/10.15587/1729-4061.2016.65778

[11] Mak-Kenn, B. M. (Ed.) (2008). Struktura i tekstura pischevykh produktov. Produkty emulsionnoi prirody. Saint Petersburg, 480.

[12] Bilyk, O., Kochubei-Lytvynenko, O., Bondarenko, Y., Vasylchenko, T., Pukhliak, A. (2020). Developing an improver of targeted action for the prolonged freshness of bread made from wheat flour. Eastern-European Journal of Enterprise Technologies, 5 (11 (107)), 62-70. doi: http://doi.org/10.15587/1729-4061.2020.214934

[13] Bairamov, E. E. (2015). Polipshuvachi, shcho pidvyshchuiut elastychnist i znyzhuiut roztiazhnist kleikovyny i tista. Kharchova promyslovist, 18, 13-18.

[14] Khazenkhiuttlia, Dzh., Gartela, R. (Eds.) (2008). Pischevye emulgatory i ikh primenenie. Saint Petersburg, 287.

[15] Tochnaia nastroika muki. Muhlenchemie. Available at: https://swg.showpad.com/share/bXr362bWQZ8yBTv99zxij

[16] Bobyshev, K. A., Matveeva, I. V., Iudina, T. A. (2013). Vliianie askorbinovoi kisloty na svoistva testa i kachestvo khleba. Pischevye ingredienty. Syre i dobavki, 1, 52-55.

[17] Drobot, V. I. (Ed.) (2015). Tekhnokhimichnyi kontrol syrovyny ta khlibobulochnykh i makaronnykh vyrobiv. Kyiv: NUKhT, 902.

[18] Generally Recognized As Safe. Available at: https://de.wikipedia.org/wiki/Generally_Recognized_As_Safe

[19] Ziuzko, A. S., Korostova, E. V., Bondarenko, V. I. (2011). Razrabotka kompleksnogo uluchshitelia dlia povysheniia kachestva khleba iz pshenichnoi muki. Izvestiia vuzov. Pischevaia tekhnologiia, 4, 24-25. 